\title{
Front Matter: Volume 9239
}

, "Front Matter: Volume 9239," Proc. SPIE 9239, Remote Sensing for Agriculture, Ecosystems, and Hydrology XVI, 923901 (11 November 2014); doi: $10.1117 / 12.2177766$

SPIE. Event: SPIE Remote Sensing, 2014, Amsterdam, Netherlands 


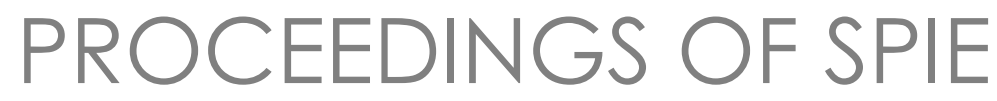

\title{
Remote Sensing for Agriculture, Ecosystems, and Hydrology XVI
}

\author{
Christopher M. U. Neale \\ Antonino Maltese \\ Editors
}

\section{3-25 September 2014 Amsterdam, Netherlands}

Sponsored by

SPIE

Cooperating Organisations

European Association of Remote Sensing Companies (Belgium)

Remote Sensing and Photogrammetry Society (United Kingdom)

European Optical Society

CENSIS—Innovation Centre for Sensor \& Imaging Systems

EUFAR-European Facility for Airborne Research

EARSeL-European Association of Remote Sensing Laboratories

TNO

ESA

Published by

SPIE 
The papers included in this volume were part of the technical conference cited on the cover and title page. Papers were selected and subject to review by the editors and conference program committee. Some conference presentations may not be available for publication. The papers published in these proceedings reflect the work and thoughts of the authors and are published herein as submitted. The publisher is not responsible for the validity of the information or for any outcomes resulting from reliance thereon.

Please use the following format to cite material from this book:

Author(s), "Title of Paper," in Remote Sensing for Agriculture, Ecosystems, and Hydrology XVI, edited by Christopher M. U. Neale, Antonino Maltese, Shahid Habib, Proceedings of SPIE Vol. 9239 (SPIE, Bellingham, WA, 2014) Article CID Number.

ISSN: 0277-786X

ISBN: 9781628413021

Published by

SPIE

P.O. Box 10, Bellingham, Washington 98227-0010 USA

Telephone +1 3606763290 (Pacific Time) · Fax +1 3606471445

SPIE.org

Copyright (@ 2014, Society of Photo-Optical Instrumentation Engineers.

Copying of material in this book for internal or personal use, or for the internal or personal use of specific clients, beyond the fair use provisions granted by the U.S. Copyright Law is authorized by SPIE subject to payment of copying fees. The Transactional Reporting Service base fee for this volume is $\$ 18.00$ per article (or portion thereof), which should be paid directly to the Copyright Clearance Center (CCC), 222 Rosewood Drive, Danvers, MA 01923. Payment may also be made electronically through CCC Online at copyright.com. Other copying for republication, resale, advertising or promotion, or any form of systematic or multiple reproduction of any material in this book is prohibited except with permission in writing from the publisher. The CCC fee code is 0277-786X/14/\$18.00.

Printed in the United States of America.

Publication of record for individual papers is online in the SPIE Digital Library.

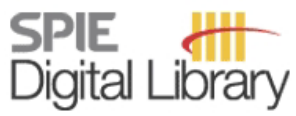

SPIEDigitallibrary.org

Paper Numbering: Proceedings of SPIE follow an e-First publication model, with papers published first online and then in print and on CD-ROM. Papers are published as they are submitted and meet publication criteria. A unique, consistent, permanent citation identifier (CID) number is assigned to each article at the time of the first publication. Utilization of CIDs allows articles to be fully citable as soon as they are published online, and connects the same identifier to all online, print, and electronic versions of the publication. SPIE uses a six-digit CID article numbering system in which:

- The first four digits correspond to the SPIE volume number.

- The last two digits indicate publication order within the volume using a Base 36 numbering

system employing both numerals and letters. These two-number sets start with 00, 01, 02, 03, 04, 05, 06, 07, 08, 09, 0A, 0B ... 0Z, followed by 10-1Z, 20-2Z, etc.

The CID Number appears on each page of the manuscript. The complete citation is used on the first page, and an abbreviated version on subsequent pages. Numbers in the index correspond to the last two digits of the six-digit CID Number. 


\title{
Contents
}

\author{
ix Authors \\ xi Conference Committee \\ xiii Introduction \\ $\mathrm{xv} \quad$ Remote sensing at the NASA Kennedy Space Center and the Eastern Range: a \\ perspective from the ground up (Plenary Paper) [9241-100]
}

\section{SESSION 1 MICROWAVE AND RADAR APPLICATIONS}

923903 Passive microwave response to vegetation and soil moisture on agricultural fields [9239-2]

923904 Rainfall estimation with a commercial tool for satellite internet in Ka band: concept and preliminary data analysis [9239-3]

923905 The effect of land cover type on radar altimeter response and its influence on retracker algorithms [9239-4]

923906 A study on the use of passive microwave radiometry for the detection of buried objects and their associated hydrological changes [9239-5]

\section{SESSION 2 THERMAL INFRARED REMOTE SENSING}

923907 Combining land surface models and remote sensing data to estimate evapotranspiration for drought monitoring in Europe (Invited Paper) [9239-6]

923908 Surface soil water content estimation based on thermal inertia and Bayesian smoothing [9239-8]

923909 Temperature monitoring along the Rhine River based on airborne thermal infrared remote sensing: qualitative results compared to satellite data and validation with in situ measurements [9239-9]

\section{SESSION 3 MONITORING OF RANGELAND AND FORESTS}

$9239 \mathrm{OB} \quad$ Integrating remote sensing and conventional grazing/browsing models for modelling carrying capacity in Southern African rangelands [9239-13]

9239 OC The potential of Sentinel-2 spectral configuration to assess rangeland quality [9239-15] 
9239 OD Quantitative assessment of Australian plague locust habitats in the inland of eastern Australia using RS and GIS technologies [9239-17]

$9239 \mathrm{OF}$ Identification of long-term trends in vegetation dynamics in the Guinea savannah region of Nigeria [9239-21]

9239 OG Object based technique for delineating and mapping 15 tree species using VHR WorldView-2 imagery [9239-23]

SESSION 4 UTILIZATION AND VALIDATION OF RS OBSERVATIONS AND TOOLS FOR HYDROLOGY, AGRICULTURE, AND FLOOD MAPPING AND MODELING

$9239 \mathrm{OH}$ Hemispherical directional reflectance factor using UAV and a hyperspectral camera, validation and crop field test [9239-11]

9239 ol Suitability of DSM derived from remote sensing data for automatic drainage extraction [9239-12]

9239 0J Multi-hazard risk analysis using the FP7 RASOR Platform [9239-14]

9239 OK Evapotranspiration and energy balance components spatial distribution in the north region of Minas Gerais, Brazil, using the SEBAL model and Landsat 5 TM images [9239-16]

\section{SESSION 5 ENERGY BALANCE AND EVAPOTRANSPIRATION I}

923900 Energy balance with Landsat images in irrigated central pivots with corn crop in the São Paulo State, Brazil [9239-25]

9239 OP Improvements in irrigation system modelling when using remotely sensed ET for calibration [9239-26]

$9239 \mathrm{OQ}$ Estimation of land surface albedo time series and trends based on MODIS data [9239-27]

\section{SESSION 6 ENERGY BALANCE AND EVAPOTRANSPIRATION II}

9239 OS Vineyard zonal management for grape quality assessment by combining airborne remote sensed imagery and soil sensors [9239-29]

9239 ОT E.O.-based estimation of transpiration and crop water requirements for vineyards: a case study in southern Italy [9239-30]

\section{SESSION 7 CROP YIELD MONITORING}

9239 OV Analyzing C-band SAR polarimetric information for LAI and crop yield estimations [9239-32]

9239 OW Coupling MODIS images and agrometeorological data for agricultural water productivity analyses in the Mato Grosso State, Brazil [9239-33] 
9239 0X A spectral-spatial-dynamic hierarchical Bayesian (SSD-HB) model for estimating soybean yield [9239-34]

9239 OY Estimation of corn and soybeans yield using remote sensing and crop yield data in the United States [9239-35]

SESSION 8 HIGH-RESOLUTION REMOTE SENSING: SPATIAL AND SPECTRAL

923910 Vegetation index correction to reduce background effects in orchards with high spatial resolution imagery (Best Student Paper Award) [9239-37]

923911 Insights and recommendations of use of UAV platforms in precision agriculture in Brazil [9239-38]

923912 UAV-based hyperspectral monitoring of small freshwater area [9239-39]

923913 Hyperspectral remote sensing for estimating coastal water quality: case study on coast of Black Sea, Romania [9239-40]

923914 Hyperspectral band selection and classification of Hyperion image of Bhitarkanika mangrove ecosystem, eastern India [9239-41]

923915 Independent Component Analysis (ICA) performance to bathymetric estimation using high resolution satellite data in an estuarine environment [9239-77]

\section{SESSION 9 WATER RESOURCES I}

923918 Analysis of snow spatial and temporary variability through the study of terrestrial photography in the Trevelez River valley [9239-45]

923919 Drainage network extraction of Brazilian semiarid region with potential flood indication areas [9239-46]

9239 1A A remote sensing and geochemical tracing approach for localising groundwater discharge to lakes [9239-47]

\section{SESSION 10 WATER RESOURCES II}

9239 1B A model based on satellite altimetry and imagery to evaluate water volume changes in a reservoir in Brazil [9239-49]

9239 1C Delimitation of permanent protected areas of rivers in Brazil [9239-50]

9239 ID Acquisition of underwater topography in a mountain channel using terrestrial laser scanning [9239-51] 
$92391 \mathrm{E}$ The use of full range spectroradiometer data to assess properties of a heterogeneous soil set in a regional scale survey [9239-52]

9239 IF Automatic detection and agronomic characterization of olive groves using high-resolution imagery and LIDAR data [9239-53]

9239 1G Accurate crop classification using hierarchical genetic fuzzy rule-based systems [9239-54]

SESSION 12 CHANGE DETECTION AND VEGETATION MONITORING

$923911 \quad$ A new approach for agroecosystems monitoring using high-revisit multitemporal satellite data series [9239-58]

9239 IK Estimating primary productivity of tropical oil palm in Malaysia using remote sensing technique and ancillary data [9239-60]

$92391 \mathrm{~N} \quad$ Remote sensing evaluation of ecosystem service value of gas regulation with time series Landsat images [9239-63]

\section{POSTER SESSION}

$92391 \mathrm{R} \quad$ Retrieval of LAl and leaf chlorophyll content from remote sensing data by agronomy mechanism knowledge to solve the ill-posed inverse problem [9239-68]

9239 is Validation of smoke plume rise models using ground-based Lidar [9239-70]

9239 IV Remote sensing of climate changes effects on forest biophysical variables [9239-74]

9239 1X Land drainage system detection using IR and visual imagery taken from autonomous mapping airship and evaluation of physical and spatial parameters of suggested method [9239-76]

923912 Pasture evapotranspiration as indicators of degradation in the Brazilian Savanna: a case study for Alto Tocantins watershed [9239-79]

923920 Spectral reflectance of satellite images using geostatistics methods to estimate growth and cotton yield [9239-80]

923922 Remote sensing of water level and ice cover of large and middle-sized lakes of Russia [9239-84]

923923 Simulating the spatial representativeness of the meteorological observed data on rugged terrain [9239-85]

923924 Biophysical parameters in a wheat producer region in southern Brazil [9239-87]

923926 Assessing Cd-induced stress from plant spectral response [9239-89] 
923927 The synergy of water quality and sea surface currents data in determining the spatiotemporal evolution of large-scale circulation features [9239-90]

923928 Monitoring displacements of an earthen dam using GNSS and remote sensing [9239-91]

9239 2B Evaluating the potential of GeoEye data in retrieving LAl at watershed scale [9239-94]

$92392 \mathrm{E}$ Water productivity of different land uses in watersheds assessed from satellite imagery Landsat 5 Thematic Mapper [9239-86]

$92392 \mathrm{~F}$ An improved model for sensible heat flux estimation based on landcover classification [9239-81] 
Proc. of SPIE Vol. $9239923901-8$

Downloaded From: https://www.spiedigitallibrary.org/conference-proceedings-of-spie on 26 Apr 2023 Terms of Use: https://www.spiedigitallibrary.org/terms-of-use 


\title{
Authors
}

Numbers in the index correspond to the last two digits of the six-digit citation identifier (CID) article numbering system used in Proceedings of SPIE. The first four digits reflect the volume number. Base 36 numbering is employed for the last two digits and indicates the order of articles within the volume. Numbers start with 00, 01, 02, 03, 04, 05, 06, 07, 08, 09, OA, OB...0Z, followed by 10-1Z, 20-2Z, etc.

\author{
Addesso, Paolo, 08 \\ Adjorlolo, C., OB \\ Almeida, R., 15 \\ Andrade, Ricardo G., 0O, 0W, 1Z, 24 \\ Aquilino, Mariella, 2B \\ Asano, Y., ID \\ Ashokkumar, L., 14 \\ Barbré, Robert E., Jr., XV \\ Baschek, Björn, 09 \\ Benas, Nikolaos, $0 Q$ \\ Bolfe, Edson L., 0O, OW, 24 \\ Bonilla, I., OS \\ Botha, J. O., OB \\ Brandão, Ziany N., 11, 20 \\ Bullock, P. R., 03 \\ Cammalleri, C., 07 \\ Capodici, Fulvio, 08, 27, 28 \\ Caruso, T., IF \\ Cho, Moses, OC \\ Chrysoulakis, Nektarios, $\mathrm{OQ}$ \\ Ciraolo, Giuseppe, 27 \\ Coppin, Pol, 10 \\ Cosoli, Simone, 27 \\ Cracknell, A. P., 1K \\ Cruz, Caroline R., OW, 24 \\ Cuccoli, Fabrizio, 04 \\ Cuellar, Miguel Zanic, 19 \\ Culcea, Oana, 13 \\ D'Addario, Larry, xv \\ Dardanelli, Gino, 28 \\ de C. Abreu, Luiza Gontijo Álvares, 1B \\ Decker Ryan K., xV \\ Deckers, Tom, 10 \\ de Freitas Oliveira, João Ricardo, 19, 1C \\ de Jeu, Richard, 06 \\ de Oliveira Ortiz, Jussara, 19 \\ de Paula Boratto, Isa M., OK \\ Dida, Adrian I., IV \\ Diez, M., 11 \\ Duro, Javier, 0J \\ D'Urso, Guido, 08, 0T \\ Eddy, Andrew, OJ \\ Franco, Renato A. M., 2E \\ Fricke, Katharina, 09 \\ Garella, Riccardo, 08 \\ Geldzahler, Barry, xv \\ Geniataki, Sofia, Ol \\ Gentile, Francesco, 2B \\ Georgiev, Georgi, 26
}

Ghezehegn, S. G., 13

Gianou, Stefania, 0 I

Gomide, Reinaldo L., OK

Gonçalves, M., 15

Gong, Lifeng, 23

Grego, Célia R., 20

Gu, Xiaohe, 1N, 1Q

Guo, Wei, 1N

Haarbrink, Roland, 06

Habeeb, Hindav N., OG

Hakala, T., OH, 12

Hanssen, Ramon F., OV

Hao, W. M., is

Harbich, Monika, $1 E$

Hernandez, Fernando B. T., 00, 2E

Herrero, Javier, 18

Hommersom, Annelies, 13

Honkavaara, E., $\mathrm{OH}, 12$

Huddleston, Lisa L., xV

lacobellis, Vito, 2B

Iannini, Lorenzo, OV

Inamasu, Ricardo Y., 11, 20

Janssens, Pieter, 10

Jardim, Alexandre Copertino, 19

Jin, Xiuliang, 1Q

Jiao, Jingjun, $2 F$

Jirka, Vladimír, $1 \mathrm{X}$

Jorge, Lúcio A. C., 11, 20

Jung, András, $1 \mathrm{E}$

Kancheva, Rumiana, 26

Kanniah, K. D., 1K

Karrasch, Pierre, OF

Kazama, Yoriko, OX

Kim, Nari, OY

Koska, Bronislav, $1 \mathrm{X}$

Koudogbo, Fifamè N., OJ

Kovalev, V., IS

Křemen, Tomášs, $1 \mathrm{X}$

Krommendijk, Bram, 13

Kujirai, Toshihiro, OX

La Loggia, Goffredo, 28

La Scalia, G., IF

Lecina, S., OP

Lee, Yang-Won, OY

Leivas, Janice F., 0O, 0W, 1Z, 24

Leonardi, Silvia S., 1C

Li, Li, 23

Li, Zhenhai, $1 Q$

Lindfors, A., 12 
Liu, Qinhuo, 23

Longo, Maurizio, 08

Ludwig, Marie, 1E

Maillard, Philippe, 05, 1B

Mallandrino, Giuseppe, 27

Maltese, Antonino, 08, 0T, 27, 28

Markelin, L., $\mathrm{OH}, 12$

Marra, F. P., $1 F$

Martínez de Toda, F., OS

Martínez-Casasnovas, J. A., OS

Mastorocostas, Paris A., IG

Mathieu, Renaud, OC

Mhangara, P., OB

Miller, B., 03

Miller, Michael J., xv

Miura, N., 1D

Moclán, C., II

Molijn, Ramses A., OV

Morabito, David D., XV

Morgan, Jennifer G., xV

Mousivand, Ali, OV

Mugnai, Clio, 04

Mustafa, Yaseen T., OG

Mutanga, O., OB

Mylonas, Stelios K., $1 G$

Namikawa, Laércio M., 1C

Neale, Christopher M. U., OP

Nie, Chenwei, 1Q

Nikolakopoulos, Konstantinos G., Ol

Nils, De Reus, 13

Nogueira, Sandra F., $1 Z$

Novelli, Antonio, 2B

Nurminen, K., 12

Odindi, J., OB

Osunmadewa, Babatunde A., OF

Palladino, Mario, OT

Peng, Zhiqing, 2F

Pereira, Eric Oliveira, 05

Pérez-Palazón, María José, 18

Perfetti, Nicola, 28

Petkov, A., is

Pimentel, Rafael, 18

Pirondini, F., 11

Polo, María José, 18

Pölönen, I., 12

Pospišili, Jiř́, $1 \mathrm{X}$

Puccio, Luigi, 28

Puupponen, H.-H., 12

Ramoelo, Abel, OC

Restaino, Rocco, 08

Rocha, Carlos, 1A

Roeder, William P., xv

Romo, A., 11

Rosim, Sergio, 19, 1C

Rossi, Lauro, OJ

Rudari, Roberto, 0J

Rühl, J., $1 \mathrm{~F}$

Rybushkina, Galina, 22

Shanmugam, S., 14
Saari, H., 12

Sano, Edson E., $1 Z$

Scalise, A., IS

Sciortino, R., $1 F$

Seibert, Marc A., xV

Sepulcre-Cantó, G., 07

Sermi, Francesco, 04

Skidmore, Andrew K., OC

Somers, Ben, 10

Soustova, Irina, 22

Stavrakoudis, Dimitris G., $1 G$

Steef, Peters, 13

Štroner, Martin, $1 \mathrm{X}$

Tan, K. P., 1K

Tarantino, Eufemia, 2B

Teodoro, A. C., 15

Teixeira, Antônio Heriberto de C., 00, 0W, 1Z, 24, $2 \mathrm{E}$

Theocharis, John B., $1 G$

Thiele-Bruhn, Sören, $1 \mathrm{E}$

Tits, Laurent, 10

Topaloglou, Charalampos A., IG

Troitskaya, Yuliya, 22

Udelhoven, Thomas, $1 \mathrm{E}$

Urbanski, S., is

Van Beek, Jonathan, 10

van de Ven, Robbert, 06

van Opstal, J. D., OP

Victoria, Daniel de C., OW, 1Z, 24

Vivone, Gemine, 08

Vogt, J., 07

Vohland, Michael, 1E

Wang, Haikou, OD

Wang, Yancang, $1 \mathrm{~N}$

Wessollek, Christine, OF

Wilson, Jean, $1 \mathrm{~A}$

Wold, C., is

Xin, Xiaozhou, 23, 2F

Xu, Xingang, 1Q

Yang, Guijun, 1N, 1Q

Yu, Shanshan, 23

Zhang, Hailong, 23

Zhou, Ti, 2F

Zoran, Liviu Florin $V_{\text {., }} 1 \mathrm{~V}$

Zoran, Maria A., IV 


\title{
Conference Committee
}

\author{
Symposium Chairs
}

Charles R. Bostater Jr., Florida Institute of Technology (United States)

Symposium Co-chairs

Ulrich Michel, University of Education Heidelberg (Germany)

Bart Snijders, TNO (Netherlands)

Conference Chairs

Christopher M. U. Neale, University of Nebraska Lincoln (United States)

Antonino Maltese, Università degli Studi di Palermo (Italy)

Conference Co-chair

Shahid Habib, NASA Goddard Space Flight Center (United States)

Session Chairs

1 Microwave and Radar Applications

Christopher M. U. Neale, University of Nebraska Lincoln (United States)

2 Thermal Infrared Remote Sensing

Massimo Menenti, Technische Universiteit Delft (Netherlands)

3 Monitoring of Rangeland and Forests

Christopher M. U. Neale, University of Nebraska Lincoln (United States)

$4 \quad$ Utilization and Validation of RS Observations and Tools for Hydrology, Agriculture, and Flood Mapping and Modeling

Shahid Habib, NASA Goddard Space Flight Center (United States)

5 Energy Balance and Evapotranspiration I

Antonino Maltese, Università degli Studi di Palermo (Italy)

6 Energy Balance and Evapotranspiration II

Antonino Maltese, Università degli Studi di Palermo (Italy)

$7 \quad$ Crop Yield Monitoring

Christopher M. U. Neale, University of Nebraska Lincoln (United States) 
8 High-Resolution Remote Sensing: Spatial and Spectral

Antonino Maltese, Università degli Studi di Palermo (Italy)

9 Water Resources I

Christopher M. U. Neale, University of Nebraska Lincoln (United States)

10 Water Resources II

Christopher M. U. Neale, University of Nebraska Lincoln (United States)

11 Surface Characterization

Antonino Maltese, Università degli Studi di Palermo (Italy)

12 Change Detection and Vegetation Monitoring

Antonino Maltese, Università degli Studi di Palermo (Italy) 


\section{Introduction}

This proceedings volume contains papers presented during the conference on Remote Sensing for Agriculture, Ecosystems, and Hydrology. The conference was part of the International Symposium on Remote Sensing sponsored by SPIE. The symposium was held at the Amsterdam RAI Exhibition and Convention Centre, Amsterdam, Netherlands, 22-25 September 2014.

The conference is dedicated to providing rapid dissemination of scientific and technical information, and attracted scientists and professionals from throughout Europe, Africa, Asia, and the Americas. Approximately 48 oral and 19 poster presentations were given, covering a broad range of topics in the field of remote sensing applications in environmental science.

The program was organized according to major themes, with 12 sessions on Agriculture: Crop Yield Monitoring; Surface Characterization; Monitoring of Rangeland and Forests; Change Detection and Vegetation Monitoring; Microwave and Radar Applications; Thermal Infrared Remote Sensing; HighResolution Remote Sensing: Spatial and Spectral. Hydrology: Energy Balance and Evapotranspiration (2) and Water Resources (2).

The technical session "Utilization and Validation of RS Observations and Tools for Hydrology, Agriculture, and Flood Mapping and Modelling", was included as a joint session of the 9239 Program. We extent our thanks to Dr. Shahid Habib, from NASA Goddard Space Flight Ctr. (United States) for organizing and chairing this session.

The poster presentations also had good representation from the above-mentioned themes. The presentations described both fundamental and applications-based research activities including modelling, laboratory and field experiments, and operational applications.

We extend our gratitude to Dr. Massimo Menenti of Technische Univ. Delft (Netherlands) for chairing one of the Sessions; and to Dr. Carmelo Cammalleri (European Commission Joint Research Ctr., Italy), Dr. Wim G.M. Bastiaanssen and Dr. Massimo Menenti of Technische Univ. Delft (Netherlands) for giving three invited presentations on important topics. Our appreciation and gratitude goes also to the presenters for their efforts and to the participants for their insightful questions and discussions. Special thanks are also due to the host city for the excellent venue and to SPIE staff, and all the SPIE organizational staff for their support prior to, during 
and after the symposium. We look forward to an even more successful conference in 2015.

Christopher M. U. Neale Antonino Maltese 